\title{
Land Degradation and Soil Quality Deterioration - A Challenge to the Future Food Production
}

\section{KL Sharma*}

Former Principal Scientist and National Fellow, ICAR-Central Research Institute for

Dryland Agriculture, Santoshnagar, Hyderabad, India

*Corresponding Author: KL Sharma, Former Principal Scientist and National

Fellow, ICAR-Central Research Institute for Dryland Agriculture, Santoshnagar,

Hyderabad, India.
Received: June 22, 2021

Published: July 16, 2021

(C) All rights are reserved by KL Sharma.
In India, agriculture is considered as the backbone of the economy as the majority of the population is engaged in agriculture to earn its livelihood. It is understood that India has the second-largest arable land resources in the world and is the largest producer of spices, pulses, milk, tea, cashew, and jute, and the second largest producer of wheat, rice, fruits and vegetables, sugarcane, cotton, and oilseeds. Food grain statistics reveal that during the year 2019-20 crop year, food grain production reached to a record of 296.65 million tonnes. Whereas, the target set by the Government of India in 2020-21 for food grain production is of the order of 298 MT.

At the time of independence, the agriculture in India was in a very poor state as the food grain production during 1949-50 was just 55 MT. The increase in food grain production up to mid Sixties, though increased, but was not adequate to feed the ever-increasing population. The poor state of agriculture was attributed to use of age-old practices like low yielding traditional crop varieties, low fertiliser use, poor plant protection and weed control measures, lack of machinery, less irrigation facility and more dependence on rain-God. The short and long term droughts and dry spells frequently prevailed and pushed the country to import food grains especially, wheat. A situation came, when the country faced ship to mouth situation. Based on these adverse experiences, the country learnt the lesson and geared up towards latest technology starting with high yielding varieties, increased fertiliser use, enhanced irrigation facilities and use of effective plant protection and weed control measures. Now the situation has totally reversed and the country has become net exporter in several agricultural products. The question arises that how long the country will be able to sustain these higher targets of food grain production to feed its ever-increasing population when the land and water resources are shrinking both quantitatively and qualitatively.

There are estimates that, out of the $329 \mathrm{~m}$ ha of total geographical area in the country, the total degraded area accounts for120.7 $\mathrm{m} \mathrm{ha}$, of which $73.3 \mathrm{~m}$ ha area is affected by water erosion, $12.4 \mathrm{~m}$ ha by wind erosion, $6.73 \mathrm{~m}$ ha by salinity and alkalinity and $25 \mathrm{~m}$ ha by soil acidity. Out of the net cultivated area of about $142.0 \mathrm{~m}$ ha, about $73 \mathrm{~m}$ ha is rainfed and only about $69 \mathrm{~m}$ ha is irrigated. On the other hand, the land-holding fragmentation has increased and consequently per capita land availability has declined. As per the Agricultural Census of 2015-16, the agricultural holdings in the country have increased from 138 million during 2010-11 to about 146 million during 2015-16. Consequently, the average size of holding has decreased from 1.15 ha during 2010-11 to 1.08 ha during 2015-16. The most serious concern is that about $86.21 \%$ of the total holdings of the country are small and marginal ( 0 to 2 ha). The small and marginal farmers are resource poor and hence to raise the productivity level in these farms is utmost difficult. Land degradation and soil quality deterioration are the major threats amidst extreme climatic events likely to occur due to climate change in the near future.

Based on the Taxonomic classification, soils in India represent Entisols (80.1 m ha), Inceptisols (95.8 m ha), Vertisols (26.3 m ha), 
Aridisols (14.6), Mollisols (8.0 m ha), Ultisols (0.8 m ha), Alfisols (79.7 $\mathrm{m} \mathrm{ha}$ ), Oxisols (0.3 $\mathrm{m} \mathrm{ha}$ ) and non-classified soil (23.1 $\mathrm{m} \mathrm{ha}$ ). Considering the rainfall pattern, $15 \mathrm{~m}$ ha area falls in a rainfall zone of $<500 \mathrm{~mm}, 15 \mathrm{~m}$ ha under 500 to $750 \mathrm{~mm}, 42 \mathrm{~m}$ ha under 750 to $1150 \mathrm{~mm}$ and $25 \mathrm{~m}$ ha under $>1150 \mathrm{~mm}$ rainfall. Most of the soils in rainfed regions are at the verge of degradation having low cropping intensity, relatively low organic matter status, poor soil physical health, low fertility, etc. Moisture stress accompanied by other soil related constraints result in low productivity of majority of the crops in rainfed regions. The recent trends of climate change which include variations in minimum and maximum temperatures, excessive heating and cooling of soils, prolonged dry spells, extreme rainfall events leading to soil erosion and flash floods, cyclones, hailstorms etc. may adversely impact the land quality, soil health and crop productivity. Under these circumstances, the small and marginal farmers which dominate in rainfed areas will be the most affected group of farmers.

Soil degradation implies: i) loss in the quality or productivity of soil that is often the result of human activities, such as agriculture practices, deforestation, mining, waste disposal, and chemical spills, ii) changes in soil nutrient status, biota, loss of organic matter, deterioration of soil structure, and toxicity due to accumulations of naturally occurring or anthropogenic materials, iii) loss of agricultural productivity, negative impacts on the environment and economic stability, and exploitation of marginally suitable or virgin land, iv) loss or reduction of soil energy, v) adverse changes in its properties that limit or reduce soils, ability to perform agricultural productivity and environmental regulatory capacity, and vi) decline in over all soil quality leading to a reduction in biomass productivity and environment moderation capacity.

The predominant reasons of land degradation and poor soil quality (natural and management linked) can be broadly listed as follows: (i) washing away of top soil and organic matter associated with finer soil fractions due to water erosion, resulting in a 'big robbery in soil fertility, (ii) intensive deep tillage and inversion tillage with mold-board and disc plough resulting in (a) fast decomposition of remnants of crop residues,(b) breaking of stable soil aggregates and aggravating the process of oxidation of entrapped organic C, and (c) disturbance to the habitat of soil micro flora and fauna and loss in microbial diversity, (iii) excessive removal of plant available nutrients through intensive cropping without adequate additions or replenishment by way of manures or fertilizers and finally resulting in poor soil fertility, (iv) mono cropping without following any suitable rotation, (v) exclusion of legumes from the crop rotation, (vi) use of moderately high doses of primary nutrient fertilizers (N,P, K) especially under irrigated conditions without giving due consideration to secondary and micronutrients, leading to imbalance in nutrient status in soil, (vii) no or low use of organic manures such as FYM, Compost, Vermi-compost etc, (viii) no recycling back of farm based crop residues because of complete removal of crop residues from fields for animal fodder, and also burning of stubbles to ensure clean cultivation, (viii) poor green manuring as it competes with the regular crop for date of sowing and other resources, especially under rainfed or moisture stressed environments, (ix) nutrient losses due to leaching, volatilization and gaseous emissions occurring due to non -precise and faulty methods and (x) mining and other commercial activities such as use of top soil for other than agricultural purpose.

Considering the above, it is important to shift the focus towards restorative agricultural practices to revert the process of degradation and restore the quality of soil to achieve higher yield targets. The important strategies to protect the land from further degradation and to restore the quality of soils could be i) conservation agriculture practices (low tillage, residue retention on the soil surface and appropriate crop rotation), integrated nutrient management (INM), soil test based balanced fertilizer application, reclamation of problematic soils using suitable soil amendments, legislation to prohibit the misuse of top soil for bricks making, appropriate water management practices, safe disposal of industrial effluents containing heavy metals and other pollutants, rehabilitation of waste lands etc. These actions will not only restore the quality of the soils but will also improve their response to the added inputs or factor productivity.

\section{Volume 5 Issue 8 August 2021 (C) All rights are reserved by KL Sharma.}

